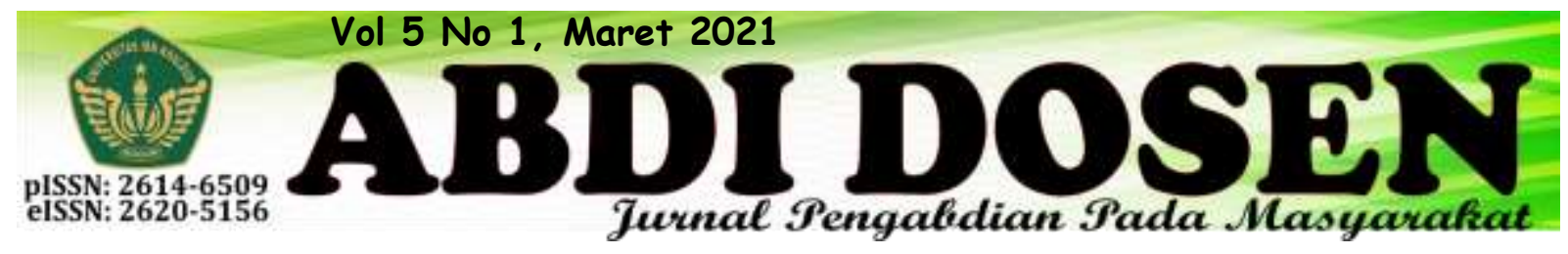

\title{
UTILIZING GOOGLE CLASSROOM AS AN ONLINE ENGLISH LEARNING MEDIA IN THE MIDDLE OF COVID-19 PANDEMIC
}

\author{
Faradila Putri $^{1}$, Eska Perdana Prasetya ${ }^{2}$ \\ faradilap97@gmail.com ${ }^{1}$ \\ eskaprasetya2013@gmail.com ${ }^{2}$ \\ English Education Department, Faculty of Teaching and Education, Universitas Ibn Khaldun, Bogor West Java, \\ Indonesia $^{1,2}$
}

\begin{abstract}
The world faces an exceptional worldwide wellbeing and financial emergency set off by the COVID-19 pandemic. In Indonesia, the lives of a great many youngsters and their families have just been overturned. Lockdowns and school terminations are influencing their instruction, emotional well-being and admittance to fundamental wellbeing administrations. The world of education is one that has received a change in policy due to the pandemic. To solve this problem, a solution is needed to solve it. Online learning is a solution to solving problems at the same time so that education in children continues. The purpose of this study was to determine the use of Google Classroom in English online learning in schools. The subjects of this research will be taken from eight-grade students at SMPN 16 Bogor. This data collection process will take place during online learning and is a descriptive study in which the researcher uses qualitative methods. This study concludes about the use of Google Classroom to simplify and improve the quality of teaching and learning activities in the midst of a pandemic.
\end{abstract}

\section{Keyword : Online Learning, Covid-19, Learning Media}

\section{INTRODUCTION}

The COVID-19 pandemic is a devastating disaster for all inhabitants of the earth. All segments of human life on earth are disturbed, including the world of education. Many countries have decided to close schools, colleges and universities, including Indonesia. The crisis really came suddenly, governments in any part of the world, including Indonesia, had to make a bitter decision to close schools to reduce people's contact massively and to save lives or still have to open schools in order to survive the workers in maintaining economic sustainability.

John Dewey (1958) argues that education is an endless process, and education is a process of forming basic abilities which are fundamental both regarding the intellectual power and emotional feelings directed at human nature and towards others. Therefore, the learning process is the key to the success of education so that the quality learning process requires quality service governance.

Based on this statement, it can be seen that education must run in any circumstances. To reduce the number of Covid-19 spread and educational activities to run as usual, the government has made several efforts to reduce this number, one of which is implemented in the education 
system in Indonesia. Teaching and learning activities have been carried out using an online system or a network system (online) since March 2020. According to (Chandrawati, 2010) that Online learning is a distance learning process by combining the principles in the learning process with technology. The learning system is carried out without face-to-face, but is carried out using a distance learning system. With the distance learning system, students are not required or obliged to come to school or campus to carry out learning. Many facilities are eventually applied by educators to carry out teaching and learning activities remotely. This means of distance learning cannot be avoided from the development of information and communication technology.

The use of Google Classroom as an online learning medium is one strategy to improve the ability and quality of the learning process in students. Google

\section{METHOD}

In this study, researchers used qualitative methods. According to (Creswell, 1994) that Research that is guided by the qualitative paradigm is defined as: "an inquiry process of understanding a social or human problem based on building a complex, holistic picture, formed with words, reporting detailed views of informants, and conducted in a natural setting. Moleong (2005:6) also said that Qualitative research is research that intends to understand the phenomena experienced by research subjects such as behavior, perception, motivation, action, etc. in a holistic manner, and by means of descriptions in the form of words and language, in a special natural
Classroom is a free online service for schools, and anyone with a Google Account. Google Classroom makes it easy for students and teachers to stay connected, both inside and outside of class. Google Classroom is a blended learning platform developed by Google for schools that aims to simplify the creation, distribution and assignment of assignments in a paperless way.

Since undergoing an online teaching and learning system, internet usage in Indonesia has increased significantly. Therefore, teachers must have adequate strategies and facilities to carry out teaching and learning activities. Communication is one of the things that requires a change when carrying out teaching and learning activities. The existence of communication is needed in the learning process, so that the teacher can control the class and students in it remotely.

context and by utilizing various natural methods.

In this study, we will describe the strategies employed by teachers in schools to implement online learning. This is an effort to ensure that student health is maintained by reducing physical contact and efforts to break the chain of Covid-19 spread in the school cluster, so as to reduce the spike in positive cases of Covid-19. This online learning uses Google Classroom as a student learning medium. The teacher can provide learning material and practice questions, and students can get the material and answer existing questions by accessing Google Classroom. 


\section{RESULT AND DISCUSSION}

Online learning that is pursued by the education party aims to ensure students continue to learn while at home and remain under teacher supervision even when the lockdown is implemented. Online learning requires teachers to better master learning media so that they can guide their students. During a pandemic, teachers are required to adapt to the learning system which is entirely conducted online and the ability of students to access the internet.

Researchers analyzed the online learning strategies carried out by the teachers. In learning, teachers use Google Classroom as a learning medium. The teacher must first create a class and will get a code that will be given to students. The code is access for students to enter the class.

\section{CONCLUSSION}

From the explanation above, we can conclude that online learning makes it very easy for teachers and students to carry out teaching and learning activities during the Covid-19 pandemic. Online learning using the internet certainly makes it very easy for teachers and students because it makes it
Google Classroom as a learning medium makes it easier for teachers to share material and assignments for students in the class.

With this research, it is known that there are several obstacles that are generally complained of by students, namely the weak internet network in their home area, the limited costs to buy the required internet quota, many of them do not have personal cellphones so they require them to borrow from their parents even There are those whose cellphones do not support using certain applications or accessing the web.

In addition, this strategy can simplify the teaching and learning process carried out remotely and make it easier for teachers to ensure that students continue to learn while at home.

easier to access the internet wherever teachers and students are. Because during the Covid-19 pandemic, we are required to maintain physical distance so that we can break the chain of transmission of Covid19. 


\section{REFERENCES}

Aji, Rizqon H.S. (2020) Dampak Covid-19 pada Pendidikan di Indonesia: Sekolah, Keterampilan, dan Proses Pembelajaran. Vol. 7 No. 5 (2020). Jurnal Sosial \& Budaya Syar-i.

Gikas, J., \& Grant, M. M. (2013). Mobile computing devices in higher education: Student perspectives on learning with cellphones, smartphones \& social media. Internet and Higher Education,

https://doi.org/10.1016/j.iheduc.2013 .06 .002

Hayati, Nur. (2020). METODE PEMBELAJARAN DARING/ELEARNING YANG EFEKTIF.

https://www.researchgate.net/public ation/340478043_METODE_PEMB ELAJARAN_DARINGE-
$\underline{L E A R N I N G \_Y A N G \_E F E K T I F \_A \_P e}$ ndahuluan_Sejarah_Elearning

Ikhsan, MZ., Prasetya, EP. (2020). Sosialisasi Pendidikan Stop Aksi Bullying. PKM-P, 4 (1).

Prasetya, E. (2018). Pemberdayaan Masyarakat Tentang Kesehatan, Pendidikan dan Kreatifitas. Abdi Dosen: Jurnal Pengabdian Pada Masyarakat 2 (1), 19-25.

Wulandari, Nadiah A. (2020) Dampak Pandemi Covid-19 Terhadap Pelaksanaan Pendidikan Di Indonesia. https://pustakabergerak.id/artikel/da mpak-pandemi-covid-19-terhadappelaksanaan-pendidikan-diindonesia-2 